\title{
Chemical Composition, Antioxidant, Antimicrobial and Antidiabetic Potential of Philodendron Bipinnatifidum Schott ex Endl
}

\author{
Jaqueline Scapinello ${ }^{1,2}$, Monica S. Z. Schindler ${ }^{1}$, Leila Zanatta ${ }^{1}$, Laura Cassol Mohr ${ }^{1}$, Ana \\ Paula Capelezzo $^{1}$, Jean Felipe Calixto ${ }^{1}$, Gean Pablo S. Aguiar ${ }^{1}$, Aline A. Boligon ${ }^{3}$, Rivaldo \\ Niero $^{4}$, Débora de Oliveira ${ }^{2}$, Jacir Dal Magro ${ }^{1}$, J. Vladimir Oliveira ${ }^{2, *}$ \\ 1. Environmental Sciences Graduate program, (Unochapecó), Chapecó, SC, Brazil \\ 2. Department of Chemical and Food Engineering, UFSC, Florianópolis, SC, Brazil \\ 3. Center of Health Sciences, UFSM, Santa Maria, RS, Brazil \\ 4. Pharmaceutical Sciences Graduate Program (UNIVALI), Itajaí, SC, Brazil \\ Email: jose.vladimir@ufsc.br (Corresponding author)
}

Received: 1 October 2019; Accepted: 24 October 2019; Available online: 30 November 2019

\begin{abstract}
Many of the species used in popular medicine do not have their biological activities already proven by scientific studies. Among these species, the endemic South American Philodendron bipinnatifidum Schott ex Endl deserves special attention since it is already in use in popular medicine for inflammation cases, such as erysipelas, orchitis and ulcers. This study evaluated the antioxidant, antimicrobial and antidiabetic activities of extracts of the hastes de P. bipinnatifidum. The ethanolic extract showed a significant antioxidant potential. The ethyl acetate extract resulted in high antimicrobial activity against Streptococcus pyogenes. The most significant biological activity of ethyl acetate extract relates to its chemical composition when compared with ethanolic extract, which showed the highest concentration of bioactive compounds. In vitro antidiabetic activity was only evaluated for ethyl acetate extract, resulting in inhibition of intestinal disaccharidases (maltase and sucrase) at concentration of $500 \mu \mathrm{g} / \mathrm{mL}$.
\end{abstract}

Keywords: Guaimbê; Flavonoids; Streptococcus pyogenes; Disaccharidases.

\section{Introduction}

The use of plants as source of prevention, treatment and cure of infectious diseases comes from empirical knowledge, acquired over many centuries and transmitted from generation to generation through popular culture. This fact arouses interest in science, which seeks, from experimental methods, to explain the commonly used plants' pharmacological activity, which are studied under the aspect of its chemical constituents [1].

The basic aim is to identify the bioactive compound in these plants and subsequently to isolate and characterize it, researching its effects on organisms justifying the medicinal activity shown by the species and also use them as active ingredient for the pharmaceutical industry $[2,3]$.

Due to the effects of acquired resistance by some bacterial microorganisms against conventional antibiotics, stemmed from the inappropriate use of these drugs by the population, new strategies are needed to control these organisms [4]. Recently, many scientists and researchers have highlighted the crude extracts and pure compounds biologically active, isolated from plant species. This fact points out to the development of new natural antimicrobial compounds, such as spices and herb extracts, which could be an alternative source of new therapies $[3,5,6]$.

Among the plants grown in Brazil, Philodendron bipinnatifidum Schott ex Endl is a shrubby specie of the Araceae family, endemic to Brazil. It is popularly known as guaimbê, banana-de-macaco or imbê. In folk medicine, people use this plant as a purgative (root), hemostatic and anthelmintic. Also there are reports of antitumor, anesthetic and anti-inflammatory activities (erysipelas, orchitis and ulcers) [7]. This plant is widely used in Brazilian folk medicine, however, there are few scientific researches about the specie, with studies on roots revealed antioxidant potential [8], branches and leaves with antiprotozoal activity [9] and antiproliferative effect of phenolic glucosides isolated from this plant on HepG2 cells [10].

The objective of this study is to obtain two different extracts of Brazilian native plant Philodendron bipinnatifidum Schott ex Endl, to characterize them and test their antioxidant, antimicrobial and antidiabetic activities in vitro. 


\section{Material and methods}

\subsection{Plant material and solvent extraction}

P. bipinnatifidum stems and leaves samples were collected on November 2016 (spring) from the native plantation of the Chapecó city, which is located approximately $659 \mathrm{~m}$ above sea level, in the Southern Region of Brazil. This region has a humid subtropical mesothermal climate. After collection, stems were manually separated from the leaves, and only the stems were cut and dried $\left(40^{\circ} \mathrm{C}\right.$ for 2 days) and then milled in an industrial blender.

The milled stems were subjected to maceration using two different solvents separately: Ethanol 99\% and ethyl acetate in a ratio of 1:20 grams of plant material per liter of solvent, and homogenized for three days at intervals of $24 \mathrm{~h}$. Thereafter, the extract was filtered and the solvent removed in rotary evaporator under reduced pressure. Finally, we frozen the extract and lyophilized it for $24 \mathrm{~h}$.

\subsection{Chemical composition of the extracts by HPLC Analysis}

All chemicals used were of analytical grade. High Performance Liquid Chromatography (HPLC-DAD) was performed with a Shimadzu Prominence Auto Sampler (SIL-20A) HPLC system (Shimadzu, Kyoto, Japan), equipped with Shimadzu LC-20AT reciprocating pumps connected to a DGU 20A5 degasser with a CBM 20A integrator, SPD-M20A diode array detector and LC solution 1.22 SP1 software.

$P$. bipinnatifidum extracts were injected into reversed phase Phenomenex $\mathrm{C}_{18}$ column $(4.6 \mathrm{~mm} \times 250 \mathrm{~mm})$ packed with $5 \mu \mathrm{m}$ diameter particles. Mobile phases A and B were Milli-Q water, acidified to $\mathrm{pH} 2.0$ with $1 \%$ of formic acid and methanol, correspondingly, solvent gradient was used as follows: 0-10 min, 5\% B; 10-25 min, $15 \%$ B; $25-40$ min, 30\%; 40-55 min 50\% B; 50-65 min 70\% B; $65-80$ min, $100 \%$ B, following the method described by Waczuk et al. (2015) with slight modifications. We filtered the sample and mobile phase through $0.45 \mu \mathrm{m}$ membrane filter (Millipore) and then degassed by ultrasonic bath prior to use. Stock solutions of standards references were prepared in the methanol: water $(1: 1, \mathrm{v} / \mathrm{v})$ at a concentration range of $0.030-0.500 \mathrm{mg} / \mathrm{mL}$. Quantifications were carried out by integration of the peaks using the external standard method, at $270 \mathrm{~nm}$ for gallic acid; $325 \mathrm{~nm}$ for caffeic acid and chlorogenic acid; and 366 for quercetin, rutin, luteolin and apigenin. The chromatography peaks were confirmed by comparing its retention time with those of reference standards and by DAD spectra (200 to $600 \mathrm{~nm})$. Calibration curve for the compounds was: gallic acid: $\mathrm{Y}=11957 \mathrm{x}+1308.1(\mathrm{r}=$ 0.9997); caffeic acid: $\mathrm{Y}=13259 \mathrm{x}+1164.5(\mathrm{r}=0.9999)$; apigenin: $\mathrm{Y}=14386 \mathrm{x}+1247.0(\mathrm{r}=0.9996)$; chlorogenic acid: $\mathrm{Y}=10985 \mathrm{x}+1274.3(\mathrm{r}=0.9998)$, quercetin: $\mathrm{Y}=12763 \mathrm{x}+1405.9(\mathrm{r}=0.9999)$; rutin: $\mathrm{Y}=10863 \mathrm{X}+1354.7$ $(r=0.9997)$ and luteolin: $Y=13462 x+1184.9(r=0.9994)$. All chromatography operations were carried out at ambient temperature and in triplicate.

Limit of detection (LOD) and limit of quantification (LOQ) were calculated based on the standard deviation of the responses and the slope using three independent analytical curves, as defined by [11]. LOD and LOQ were calculated as 3.3 and $10 \sigma / \mathrm{S}$, respectively, where $\sigma$ is the standard deviation of the response and $\mathrm{S}$ is the slope of the calibration curve. Gallic acid: LOD $0.024 \mu \mathrm{g} / \mathrm{mL}$, LOQ $0.079 \mu \mathrm{g} / \mathrm{mL}$. Chlorogenic acid: LOD $0.013 \mu \mathrm{g} / \mathrm{mL}$, LOQ $0.042 \mu \mathrm{g} / \mathrm{mL}$. Caffeic acid: LOD $0.017 \mu \mathrm{g} / \mathrm{mL}$, LOQ $0.056 \mu \mathrm{g} / \mathrm{mL}$. Rutin: LOD $0.008 \mu \mathrm{g} / \mathrm{mL}$, LOQ 0.026 $\mu \mathrm{g} / \mathrm{mL}$. Quercetin: LOD $0.011 \mu \mathrm{g} / \mathrm{mL}$, LOQ $0.035 \mu \mathrm{g} / \mathrm{mL}$. Luteolin: LOD $0.025 \mu \mathrm{g} / \mathrm{mL}$, LOQ $0.083 \mu \mathrm{g} / \mathrm{mL}$. Apigenin: LOD $0.009 \mu \mathrm{g} / \mathrm{mL}$, LOQ $0.029 \mu \mathrm{g} / \mathrm{mL}$.

\subsection{Analyses of antioxidant activity}

\subsubsection{FRAP assay for antioxidant capacity}

Ferric reducing antioxidant power (FRAP) assay was performed in triplicate, as described by [12], with some modifications. Different dilutions of seed extract $(2.50-160.00 \mu \mathrm{g} / \mathrm{mL})$ were incubated with the working solution of $10 \mathrm{mM}$ TPTZ (2, 4, 6-Tripyridyl-s-Triazine) chloride solution, $20 \mathrm{mMFeCl}{ }_{3} \cdot 6 \mathrm{H}_{2} \mathrm{O}$ and $0.3 \mathrm{M}$ acetate buffer, at $37^{\circ} \mathrm{C}$ for 30 min. The increase of absorbance resulting from the formation of the $\mathrm{Fe}^{2+}-\mathrm{TPTZ}$ complex was registered against a blank at $595 \mathrm{~nm}$. A calibration curve of $\mathrm{FeSO}_{4}$ at $595 \mathrm{~nm}$ was constructed. The results were expressed in $\mu \mathrm{molFe}{ }^{2+} / \mathrm{ml}$.

\subsubsection{Antioxidant activity by DPPH scavenging assay}

A DPPH (2, 2-diphenyl-1-picryl hydrazyl) assay was carried out according to a previous study by [13] with some modifications. The DPPH solution was prepared by dissolving $24 \mathrm{mg}$ DPPH in $100 \mathrm{~mL}$ chloroform and then diluting the solution until the absorbance reached $1.1 \pm 0.02$ units at $517 \mathrm{~nm}$. The DPPH solution $(1.9 \mathrm{~mL})$ was mixed with $50 \mathrm{~mL}$ each of chloroform and different concentrations of $P$. bipinnatifidum extract $(10,20,40,80$ and $160 \mu \mathrm{g} / \mathrm{mL}$ ) and then incubated for 120 minutes at room temperature. A control was prepared by adding $1.9 \mathrm{~mL}$ of DPPH solution to $100 \mathrm{~mL}$ of chloroform. The absorbance was measured at $517 \mathrm{~nm}$ against a pure chloroform blank in a spectrophotometer. All results were expressed as inhibition percentage and calculated as DPPH radical 
scavenging. A standard sample (control) was considered when reading the results. The concentration of antioxidant resulting in a $50 \%$ decrease in radical absorbance ( $\mathrm{IC}_{50}$ ) was estimated for the assay by non-linear regression analysis.

\subsection{Antimicrobial activity}

The antimicrobial activity was evaluated against gram-positive bacteria Streptococcus pyogenes, Enterococcus faecalis and Listeria monocytogenes and gram-negative bacteria Pseudomnas aeruginosa, according to methodologies described previously by [14]. For inoculum preparation were selected 2-4 bacterial colonies and transferred to a sterile $0.9 \%$ saline. The solution turbidity was adjusted as compared to the 0.5 McFarland scale, yielding the equivalent concentration of about $1.5 \times 10^{8}$ cells $\mathrm{mL}^{-1}$.

\subsubsection{Agar plug diffusion method}

In this technique, we seeded the microorganism of interest in Petri dishes with a culture medium Plate Count Agar (PCA) using a swab. Three equidistant holes were made in each plate, with $0.8 \mathrm{~cm}$ diameter approximately. In each hole was deposited an extract at a $0.40 \mathrm{~g} / \mathrm{mL}$ concentration and incubated at $36{ }^{\circ} \mathrm{C}$ for $24 \mathrm{~h}$. Then, we assessed the formation of a microbial growth inhibition zone, and performed the measurements using a caliper.

\subsubsection{Minimum inhibitory concentration (MIC)}

In MIC method, the highest extract concentration tested was $10.00 \mathrm{mg} / \mathrm{mL}$, and the lowest concentration tested was $0.05 \mu \mathrm{g} / \mathrm{mL}$ obtained by dilution in aqueous $0.1 \%$ Tween 80 . We performed the filtration of extracts with Millipore filter 0.45 micrometres to ensure its sterility.

The assay was performed in sterile 96-well microplates bottomed "U". To each well was added $100 \mu \mathrm{L}$ of Brain Heart Infusion broth (BHI) and $100 \mu \mathrm{L}$ extract, along with $5 \mu \mathrm{L}$ of solution containing the microorganism in a concentration of about $1,5 \times 10^{8}$ cells $/ \mathrm{mL}$. For the control tests, the wells of positive control were filled with 100 $\mu \mathrm{L}$ of $\mathrm{BHI}$ and $5 \mu \mathrm{L}$ of microorganisms, the negative control was $100 \mu \mathrm{L}$ of BHI, $100 \mu \mathrm{L}$ of $0.5 \%$ Tween 80 and $5 \mu \mathrm{L}$ microorganisms. Also it made blank test, which consisted only of $100 \mu \mathrm{L}$ of BHI.

The microplates were incubated at $36{ }^{\circ} \mathrm{C}$ for $20 \mathrm{~h}$. After this time, we added to each well $20 \mu \mathrm{L}$ of TTC (2,3,5trifeniltetrazólico chloride) an agent promoting the microbial cells coloring, making it possible to visualize bacterial growth. The microplates were returned to bacteriological incubator for a further 4 hours and then taken for reading. In order to evaluate the minimum bactericidal concentration (MBC) for every test tube in which microbial growth was not identified, the inoculum was then placed into Petri dishes with Agar Mueller-Hinton as the culture media to confirm which the lowest concentration at which bacteria failed to grow and caused microorganism death.

\subsection{Total sugars analysis}

The phenol-sulfuric method was used to analyze the total sugars according to [15]. The glucose standard solutions for calibration curve were $1.0 ; 0.80 ; 0.60 ; 0.40 ; 0.20 ; 0.10$ and $0.05 \mathrm{~g} / \mathrm{L}$. In the tubes were pipetted into $50 \mathrm{uL}$ of the standard solution or the sample, $0.450 \mathrm{~mL}$ of water, $0.5 \mathrm{~mL}$ of phenol $5 \%$ and $2.5 \mathrm{~mL}$ of concentrated sulfuric acid. After cooled the solutions, absorbance reading was performed at $490 \mathrm{~nm}$. The color change is proportional to the amount of sugar present in the sample and the result is expressed in equivalent mg glucose per $100 \mathrm{~g}$ of sample.

\subsection{Intestinal disaccharidases activity}

For this test only the extract obtained through the ethyl acetate solvent was used in the following concentrations: 250, 500 and $1000 \mu \mathrm{g} / \mathrm{mL}$.

The experimental protocol was approved by the local Ethics Committee on Animal Use (CEUA Number 004/2017). We used male Wistar rats weighing 160-200 g (50-55 day-old) from Central Animal HouseUnochapecó. After euthanasia, a segment of the small intestine was removed, washed in $0.9 \% \mathrm{NaCl}$ solution, dried on filter paper, weighed, trimmed and homogenized (300 rpm) with $0.9 \% \mathrm{NaCl}$ (400 mg duodenum per mL) for 1 min at $4{ }^{\circ} \mathrm{C}$. The resulting extract was centrifuged at $8000 \mathrm{rpm}$ for $8 \mathrm{~min}$. The supernatant was used for the measurement of sucrase, lactase and maltase activity and protein determination [16]. Maltase, lactase and sucrase activities were determined using a glucose diagnosis kit based on the reagent glucose oxidase. To determinate the disaccharidase activity, $10 \mu \mathrm{l}$ of supernatant were incubated at $37{ }^{\circ} \mathrm{C}$ for $60 \mathrm{~min}$ in maleate buffer (pH 6.0) containing sucrose, lactose or maltose and the extract.

One enzyme unit (U) was defined as the amount of enzyme that catalysed the release of $1 \mu$ mol of glucose per min under the assay conditions. The specific activity was defined as enzyme activity (U) per mg of protein. Protein concentration was determined by the method described in [17] using bovine serum albumin as the standard. The assays were performed in duplicate and conducted along with appropriate controls. 


\section{Results and discussion}

The P. bipinnatifidum stems extracts showed high antioxidant activity from DPPH assay. This method is based on the ability of the antioxidant compound to transfer electrons to DPPH and lose its characteristic purple coloring, and is considered simple and sensitive, allowing a better correlation between the concentration of samples and the percentage inhibition of DPPH [18]. Figure 1 shows percent inhibition of DPPH radical oxidation as a function of the concentrations of $P$. bipinnatifidum stems extract. Ethanolic and ethyl acetate extracts reached $75.34 \pm 0.11 \%$ and $80.81 \pm 0.79 \%$ at the concentration of $160 \mu \mathrm{g} / \mathrm{mL}$, respectively.

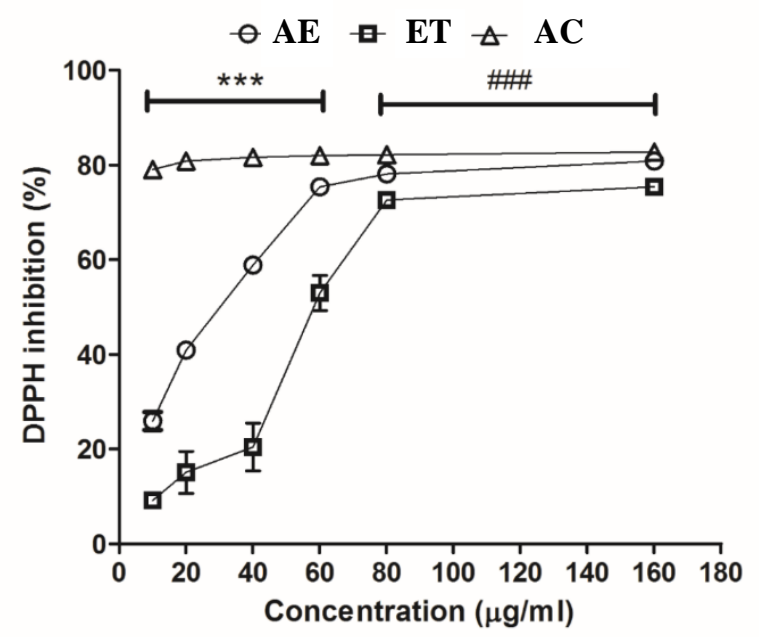

Figure 1. Percent inhibition of DPPH radical oxidation as a function of the concentrations of P. bipinnatifidum stems extracts and acid ascorbic. $* * *$ Different from ascorbic acid (AC) and different between extracts ethyl acetate (AE) and ethanol (ET) at the same concentration $(P<0.001$, ANOVA/Tukey). \#\#\# Not different between extracts, not different between extract $\mathrm{AE}$ and ascorbic acid and different between extract ET and ascorbic acid at the same concentration $(P<0.001$, ANOVA/Tukey).

For the lowest concentrations tested, both extracts resulted in significantly less antioxidant activity than the ascorbic acid $(P<0.001)$, which showed antioxidant activity above $78 \%$ already at the lowest concentration. For the highest concentrations tested ( 80 and $160 \mu \mathrm{g} / \mathrm{mL}$ ), the ethyl acetate extract had antioxidant activity comparable with ascorbic acid $(P<0.001)$ (Fig. 1$)$.

We calculated the half maximal inhibitory concentration $\left(\mathrm{IC}_{50}\right)$ by the reduction of $50 \%$ of the initial DPPH concentration, through the regression analysis. The $\mathrm{IC}_{50}$ values found for the $P$. bipinnatifidum stems extracts were $59.43 \mu \mathrm{g} / \mathrm{mL}$ for the fraction extracted with ethanol and $27.11 \mu \mathrm{g} / \mathrm{mL}$ for the ethyl acetate. Antioxidants are a type of complex compounds found in plants that act as a protective shield of our body against certain human diseases, such as arthritis, cancer, diabetes, atherosclerosis, ischemia, failures in immunity and endocrine functions [19], and the $P$. bipinnatifidum seems to be a plant that has large quantities of these compounds.

The antioxidant assay by FRAP is based on electron transfer, that measures the capacity of an antioxidant (water soluble in acidic $\mathrm{pH}$ ) in ferric-to-ferrous ions reduction, which present different colors in solution, and the degree of color change is proportional to the concentration of antioxidant contained in the sample [12]. Similar results to the DPPH method were found by the FRAP method, since the antioxidant activity increased with the increase of extract concentration, as we can see in Figure 2. Again, the antioxindant activity was more significant for the ethyl acetate extract, being comparable to the ascorbic acid in the concentrations of 80 and $160 \mu \mathrm{g} / \mathrm{mL}$.

The extract we obtained with solvent ethanol showed a weak inhibition against $S$. pyogenes microorganism, resulting in inhibition zone of $1.287 \pm 0.025 \mathrm{~cm}$, since the extract obtained with ethyl acetate solvent showed strong inhibition, resulting in inhibition zone of $3.565 \pm 0.06 \mathrm{~cm}$. In the tests of MIC and MBC, ethanol extract did not show antimicrobial activity at the concentrations tested, and the ethyl acetate extract resulted in MIC and MBC of $3.20 \mathrm{mg} / \mathrm{mL}$. For the E. faecalis and Listeria monocytogenes microorganisms, only the ethyl acetate extract resulted antimicrobial activity, with inhibition zone of $1.33 \pm 0.034 \mathrm{~cm}$ and $1.40 \pm 0.058 \mathrm{~cm}$, respectively. The MIC and MBC were $10.0 \mathrm{mg} / \mathrm{mL}$ for both microorganisms. There was no antimicrobial activity against $P$. aeruginosa for both extracts (Table 1 ).

The antimicrobial activity of the extracts observed for $S$. pyogenes is a very interesting result, since this plant is used in popular medicine for the treatment of erysipelas, a bacterial infection caused by Streptococcus pyogenes (Streptococcus group A). In addition, S. pyogenes is one of the most important bacterial causes of cutaneous and 
soft tissue infections worldwide, being reported that cellulitis and erysipelas can be mild or moderately severe, whereas other diseases, as necrotizing fasciitis, myonecrosis and StrepTSS are life-threatening [20].

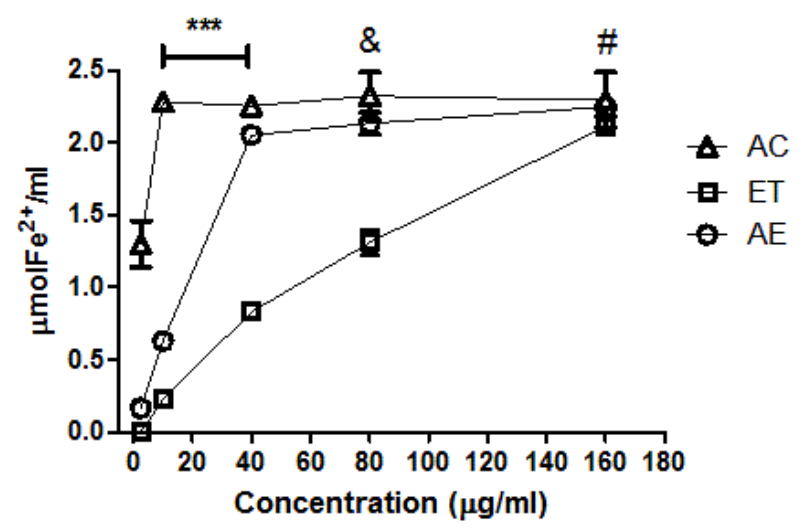

Figure 2. Antioxidant activity measured by FRAP ( $\mu \mathrm{mol} \mathrm{Fe}^{2+}$ equivalent per $\mathrm{mL}$ ) as a function of the concentrations of $P$. bipinnatifidum stems extracts and acid ascorbic. *** Different from ascorbic acid (AC) and different between extracts ethyl acetate (AE) and ethanol (ET) at the same concentration $(P<0.001$, ANOVA/Tukey). \& Different between extracts, not different between extract AE and ascorbic acid and different between extract ET and ascorbic acid $(P<0.001$, ANOVA/Tukey). \# Not different between extracts and ascorbic acid $(P>0.05$ ANOVA/Tukey).

Table 1. Antimicrobial activity of $P$. bipinnatifidum extracts.

\begin{tabular}{lllll}
\hline Microorganism & Solvent Extract & $\begin{array}{l}\text { Inhibition zone } \\
\text { diameter }(\mathrm{cm})\end{array}$ & $\begin{array}{l}\text { MIC } \\
(\mathrm{mg} / \mathrm{mL})\end{array}$ & MBC (mg/mL) \\
\hline S. pyogenes & Ethanol & $1.287 \pm 0.025$ & $\mathrm{nd}$ & $\mathrm{nd}$ \\
& Ethyl acetate & $3.565 \pm 0.060$ & 3.20 & 3.20 \\
E. faecalis & Ethanol & nd & nd & nd \\
Listeria & Ethyl acetate & $1.330 \pm 0.034$ & 10.00 & 10.00 \\
monocytogenes & Ethanol & nd & nd & nd \\
P. aeruginosa & Ethyl acetate & $1.400 \pm 0.058$ & 10.00 & 10.00 \\
& Ethanol & nd & nd & nd \\
\hline
\end{tabular}

* nd - not detected

It is possible to observe that the gram-positive bacteria were more susceptible than gram-negative for the extract. The bacteria cell envelope is a complex multilayered structure that serves to protect these organisms. Gramnegative bacteria have thin peptidoglycan cell wall, which itself is surrounded by an outer membrane containing lipopolysaccharide. Gram-positive bacteria lack an outer membrane but are surrounded by layers of peptidoglycan many times thicker than is found in the Gram-negatives, that contain through these layers, long anionic polymers, called teichoic acids [21].

The difference between the antimicrobial activities observed for extracts with different solvents can be evaluated through the chemical composition, then the HPLC profile of $P$. bipinnatifidum extracts with ethanol and ethyl acetate were acquired (Fig. $3-\mathrm{A}$ and B). The ethanol extract contains gallic acid (retention time- $\mathrm{t}_{\mathrm{R}}=10.53$ min, peak 1), chlorogenic acid $\left(t_{R}=19.24\right.$ min, peak 2), quercetin $\left(t_{R}=48.06\right.$ min, peak 5), luteolin $\left(t_{R}=57.39\right.$ min, peak 6) and apigenin $\left(t_{R}=63.85 \mathrm{~min}\right.$, peak 7). For ethyl acetate extract, the presence of these compounds were also detected but other two were observed, caffeic acid $\left(t_{R}=25.06\right.$ min, peak 3$)$ and rutin $\left(t_{R}=34.71 \mathrm{~min}\right.$, peak 4).

Through the quantification of the compounds in the extracts (Table 2) was possible to verify the presence in higher amounts of the compounds quercetin, luteolin and apigenin in the fraction extracted with ethyl acetate, that have proven antimicrobial activity against S. pyogenes [22,23]. According to [23] the inhibitory mode of action of luteolin and quercetin may be mediated inhibiting of peptidoglycan synthesis, increasing cytoplasmic microorganisms [24,25]. Another important compound detected only in this extract was rutin, which also has antimicrobial activity proven against several microorganisms [24,25]. 

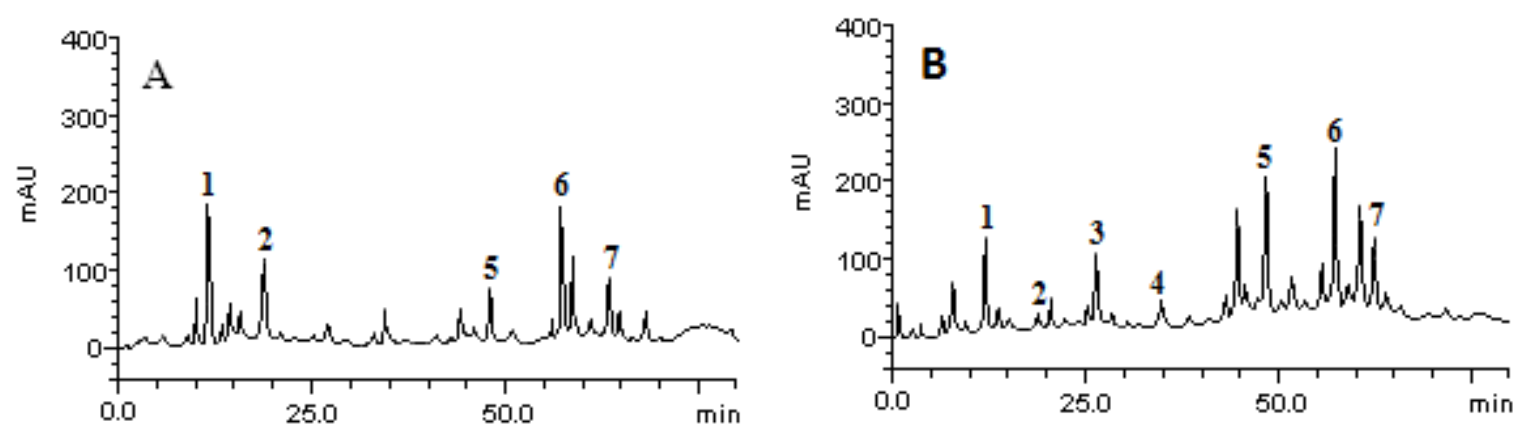

Figure 3. Representative high performance liquid chromatography profile of Philodendron bipinnatifidum extracts with ethanol (A) and ethyl acetate (B). Gallic acid (peak 1), chlorogenic acid (peak 2), caffeic acid (peak 3), rutin (peak 4), quercetin (peak 5), luteolin (peak 6) and apigenin (peak 7).

Table 2. Components of Philodendron bipinnatifidum extracts.

\begin{tabular}{lll}
\hline \multirow{2}{*}{ Compounds } & \multicolumn{1}{l}{ Ethanol } & Ethyl acetate \\
\cline { 2 - 3 } & $\mathrm{mg} / \mathrm{g}$ & $\mathrm{mg} / \mathrm{g}$ \\
\hline Gallic acid & \multicolumn{1}{c}{$9.25 \pm 0.01$} & $6.02 \pm 0.03$ \\
Chlorogenic acid & $5.47 \pm 0.03$ & $0.61 \pm 0.05$ \\
Caffeic acid & $\mathrm{Nd}$ & $4.23 \pm 0.01$ \\
Rutin & $\mathrm{Nd}$ & $1.75 \pm 0.01$ \\
Quercetin & $2.11 \pm 0.05$ & $9.47 \pm 0.04$ \\
Luteolin & $9.36 \pm 0.04$ & $11.04 \pm 0.01$ \\
Apigenin & $2.15 \pm 0.01$ & $4.19 \pm 0.02$ \\
\hline
\end{tabular}

* Results are expressed as mean \pm standard deviations (SD) of three determinations. nd - not detected.

In addition to the presence of these compounds in higher amounts in the ethyl acetate extract, another factor that may explain the lower antimicrobial activity of the ethanolic extract is the amount of sugars present in these extracts. The determination of total sugars resulted in $8915.6 \mathrm{mgEG} / 100 \mathrm{~g}$ to ethanolic extract, and 221.3 mgEG/100 g to ethyl acetate extract, proving the high amount of sugars in the extract with ethanol, which damage the antimicrobial activity, because such compounds will be used by microorganisms as carbon source for growth and proliferation.

The chemical composition of the extracts also explains the high antioxidant activity found. Within the compounds identified, ethanolic extract showed higher concentration of only one of the potent antioxidants, gallic acid, once it the highest concentration of chlorogenic compound in this extract does not contribute to the increase of antioxidant potential, according to [26], in the in vitro study, caffeic acid had stronger antioxidant activity than that of chlorogenic.

One of the compounds present in a significantly higher amount in the ethyl acetate extract is quercetin, a plantderived aglycone form of flavonoid glycosides, has been used as a nutritional supplement and may be beneficial against a variety of diseases, including cancer; it is considered as a compound with high antioxidant activity [27,28]. Other compounds that contribute to antioxidant activity of this extract are caffeic acid and rutin, both quantified only in this extract, according to [29] rutin exhibited strong DPPH radical scavenging activity and [30] reported the potent antioxidant activity of the caffeic acid.

These results demonstrate the importance of evaluating plant bioactivity resulting from different extraction methods and solvents. One cannot assert that a plant is not bioactive simply because particular plant parts do not have bioactive effects, when, for example, ethanol is used for obtaining the extract. Perhaps the extract of the same plant structure can present bioactive effects when prepared from nonpolar solvents, for example. Certainly, the extraction yield of the active component of the plant will also depend on its solubility in the solvent used.

From the best results obtained by the solvent ethyl acetate, only this one was submitted to the antidiabetic activity test. The extract inhibited the enzyme sucrase activity at concentration of 500 and $1000 \mu \mathrm{g} / \mathrm{mL}$ around $18 \%(P<0.05)$ and 30\% $(P<0.001)$, respectively, whereas at the $250 \mu \mathrm{g} / \mathrm{mL}$ no reduction was observed (Fig $4-\mathrm{a})$. For the $1000 \mu \mathrm{g} / \mathrm{mL}$, the inhibition was statistically similar to acarbose, which is a $\alpha$-glycosidases inhibitor used in clinical practice to improve glycemic control in diabetic patients, reducing the carbohydrates absorption [31]. The maltase enzyme activity was reduced by $25 \%$ when using extract concentrations of 250 and $500 \mu \mathrm{g} / \mathrm{mL}$ $(P<0.01)$, whereas at $1000 \mu \mathrm{g} / \mathrm{mL}$ there was no inhibition (Fig. $4-\mathrm{b}$ ). There was no inhibition of the enzyme lactase at the concentrations evaluated, a result similar to that seen with acarbose (Fig $4-\mathrm{c}$ ). According to [32], acarbose is a medicine that acts as an adjuvant in the treatment of diabetes, as it inhibits the maltase and sucrase 
enzymes thus preventing the disaccharides breakdown and consequent transport of glucose into the bloodstream. This compound is interesting because of this $\alpha$-glycosides restriction, since it does not induce lactose intolerance in the patient, and it does not inhibit lactase; as observed for the extract of $P$. bipinnatifidum at the $500 \mu \mathrm{g} / \mathrm{mL}$ concentration.

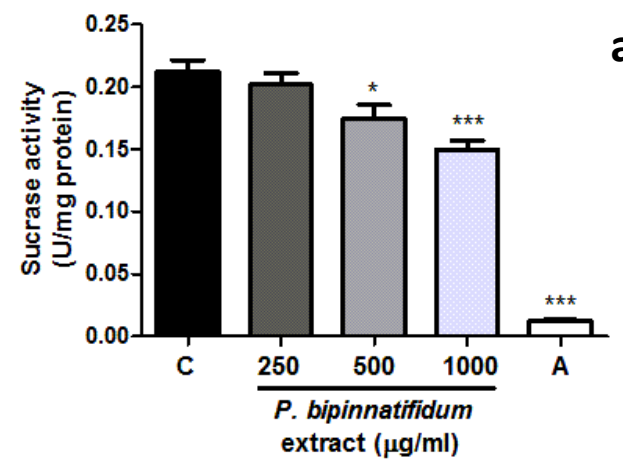

a
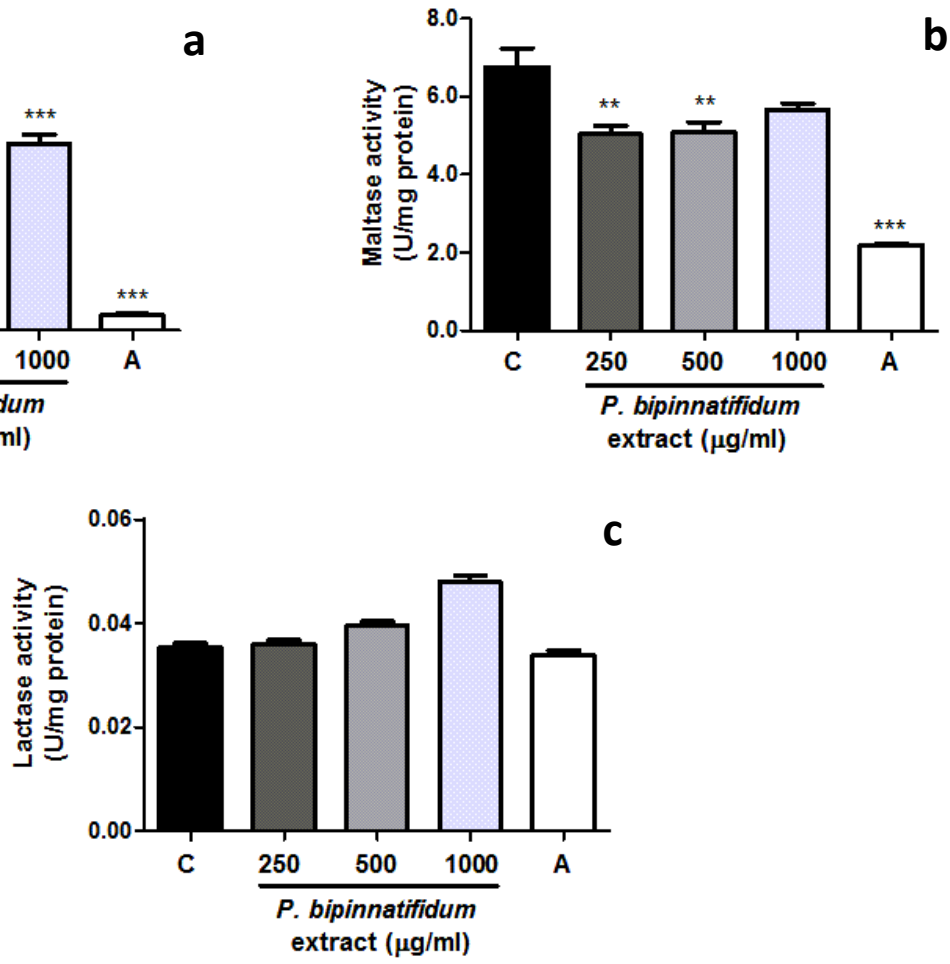

Figure 4. Effect of the P. bipinnatifidum extract (ethyl acetate) on the activity of sucrase (a), maltase (b) and lactase (c) intestinal disaccharidases. C: control; A: acarbose. Each column represents the mean \pm S.E.M. Asterisks denote statistical significance, ${ }^{*} P<0.05$, ${ }^{* *} P<0.01$ and ${ }^{* * *} P<0.001$, in relation to control group. ANOVA followed by Tukey test.

The antidiabetic potential of $P$. bipinnatifidum extract is related to the presence of flavonoids in its composition, as flavonoids may exert beneficial effects in diabetes, due enhancing insulin secretion and promoting proliferation of pancreatic $\beta$-cells, improving hyperglycemia through regulation of glucose metabolism in hepatocytes [33]. In vitro studies showed that luteolin is an effective maltase inhibitor, while lower inhibition was observed against sucrose [34]. The anti-diabetic effect of quercetin was investigated in STZ-induced diabetic mice by [35], and dietary supplementation with quercetin lowered blood glucose and enhanced serum insulin concentrations. These results demonstrate that the ethyl acetate fraction of $P$. bipinnatifidum, rich in flavonoids, should be better investigated for its antidiabetic action, by in vivo test.

\section{Conclusion}

The antimicrobial activity of $P$. bipinnatifidum extracts against $S$. pyogenes was high for the extract obtained with ethyl acetate solvent, and low for the extract obtained with ethanol. This result is directly related to the chemical composition of different extracts, where compounds with antimicrobial activity are present in greater amounts in the extract with ethyl acetate, such as quercetin, luteolin and apigenin. Antioxidant activity was high for both extracts, however due to higher concentration of flavonoids in ethyl acetate extract, this showed the highest antioxidant activity, comparable with standard solutions of ascorbic acid. Besides that, we believe that the fraction extracted with ethyl acetate exhibit a promising profile of antidiabetic potential and is good candidate for more indepth evaluation.

\section{Acknowledgement}

The authors thank CNPq, CAPES and FAPE-Unochapecó for the financial support for this research and scholarships. 


\section{References}

[1] Akram M, Hamid A, Khalil A, Ghaffar A, Tayyaba N, Saeed A, Ali M, Naveed A. Review on medicinal uses, pharmacological, phytochemistry and immunomodulatory activity of plants. International Journal of Immunopathology and Pharmacology. 2014;27(3):313-319.

[2] Brusotti G, Cesari I, Dentamaro A, Caccialanza G, Massolini G. Isolation and characterization of bioactive compounds from plant resources: the role of analysis in the ethnopharmacological approach. Journal of Pharmaceutical and Biomedical Analysis. 2014;87:218-228.

[3] Azmir J, Zaidul IS, Rahman MM, Sharif KM, Mohamed A, Sahena F, Jahurul MH, Ghafoor K, Norulaini NA, Omar AK. Techniques for extraction of bioactive compounds from plant materials: A review. Journal of Food Engineering. 2013;117(4):426-436.

[4] Thabit AK, Crandon JL, Nicolau DP. Antimicrobial resistance: impact on clinical and economic outcomes and the need for new antimicrobials. Expert Opinion on Pharmacotherapy. 2015;16(2):159-177.

[5] Palaniappan K, Holley RA. Use of natural antimicrobials to increase antibiotic susceptibility of drug resistant bacteria. International Journal of Food Microbiology. 2010;140(2-3):164-168.

[6] Xia DZ, Yu XF, Zhu ZY, Zou ZD. Antioxidant and antibacterial activity of six edible wild plants (Sonchus spp.) in China. Natural Product Research. 2011;25(20):1893-1901.

[7] Lorenzi H, Matos FJA. Medicinal plants in Brazil: native and exotic cultivated. Plantarum Institute; 2002. p.484 (in Portuguese).

[8] Menezes PR, Schwarz EA, Santos CA. In vitro antioxidant activity of species collected in Paraná. Fitoterapia. 2004;75(3):398-400.

[9] Muelas-Serrano S, Nogal JJ, Martınez-Diaz RA, Escario JA, Martınez-Fernández AR, Gómez-Barrio A. In vitro screening of American plant extracts on Trypanosoma cruzi and Trichomonas vaginalis. Journal of Ethnopharmacology. 2000;71(1-2):101-107.

[10] El-Deeb AN, Abdel-Aleem IM, El-Amin SM, Refahy LA, El-Shazly MA. Antiproliferative effect of phenolic glucosides isolated from Philodendron bipinnatifidum on HepG2 cells. Phytopharmacology. 2012;3:351-358.

[11] Boligon AA, Piana M, Kubiça TF, Mario DN, Dalmolin TV, Bonez PC, Weiblen R, Lovato L, Alves SH, Campos MM, Athayde ML. HPLC analysis and antimicrobial, antimycobacterial and antiviral activities of Tabernaemontana catharinensis A. DC. Journal of Applied Biomedicine. 2015;13(1):7-18.

[12] Benzie IF, Strain JJ. The ferric reducing ability of plasma (FRAP) as a measure of "antioxidant power": the FRAP assay. Analytical Biochemistry. 1996;239(1):70-76.

[13] Brand-Williams W, Cuvelier ME, Berset CL. Use of a free radical method to evaluate antioxidant activity. LWT-Food Science and Technology. 1995;28(1):25-30.

[14] CLSI. Methods for dilution antimicrobial susceptibility tests for bacteria that grow aerobically; 2015.

[15] Dubois M, Gilles KA, Hamilton JK, Rebers PT, Smith F. Colorimetric method for determination of sugars and related substances. Analytical Chemistry. 1956;28(3):350-356.

[16] Pereira DF, Cazarolli LH, Lavado C, Mengatto V, Figueiredo MS, Guedes A, Pizzolatti MG, Silva FR. Effects of flavonoids on $\alpha$-glucosidase activity: potential targets for glucose homeostasis. Nutrition. 2011;27(1112):1161-1167.

[17] Lowry OH, Rosebrough NJ, Farr AL, Randall RJ. Protein measurement with the Folin phenol reagent. Journal of Biological Chemistry. 1951;193:265-275.

[18] Santos MD, Lima JJ, Petkowicz CL, Candido LM. Chemical characterization and evaluation of the antioxidant potential of gabiroba jam (Campomanesia xanthocarpa Berg). Acta Scientiarum. Agronomy. 2013;35(1):73-82.

[19] Rajendran P, Nandakumar N, Rengarajan T, Palaniswami R, Gnanadhas EN, Lakshminarasaiah U, Gopas J, Nishigaki I. Antioxidants and human diseases. Clinica Chimica Acta. 2014;436:332-347.

[20] Ferretti JJ, Stevens DL, Fischetti VA. Streptococcus pyogenes: Basic biology to clinical manifestations. 2016:1-15.

[21] Silhavy TJ, Kahne D, Walker S. The bacterial cell envelope. Cold Spring Harbor Perspectives in Biology. 2010;2(5):a000414.

[22] Lucarini R, Tozatti MG, Silva ML, Gimenez VM, Pauletti PM, Groppo M, Turatti IC, Cunha WR, Martins $\mathrm{CH}$. Antibacterial and anti-inflammatory activities of an extract, fractions, and compounds isolated from Gochnatia pulchra aerial parts. Brazilian Journal of Medical and Biological Research. 2015;48(9):822-830.

[23] Siriwong S, Thumanu K, Hengpratom T, Eumkeb G. Synergy and mode of action of ceftazidime plus quercetin or luteolin on Streptococcus pyogenes. Evidence-Based Complementary and Alternative Medicine. 2015;2015. Article ID 759459.

[24] Orhan DD, Özçelik B, Özgen S, Ergun F. Antibacterial, antifungal, and antiviral activities of some flavonoids. Microbiological Research. 2010;165(6):496-504. 
[25] Dubey S, Ganeshpurkar A, Bansal D, Dubey N. Experimental studies on bioactive potential of rutin. Chronicles of Young Scientists. 2013;4(2):153.

[26] Sato Y, Itagaki S, Kurokawa T, Ogura J, Kobayashi M, Hirano T, Sugawara M, Iseki K. In vitro and in vivo antioxidant properties of chlorogenic acid and caffeic acid. International journal of pharmaceutics. 2011;403(1-2):136-138.

[27] Zhang M, Swarts SG, Yin L, Liu C, Tian Y, Cao Y, Swarts M, Yang S, Zhang SB, Zhang K, Ju S, et al. Antioxidant properties of quercetin. In:Oxygen Transport to Tissue XXXII 2011. Springer, Boston, MA. p. 283-289.

[28] Mihaylova D, Schalow S. Antioxidant and stabilization activity of a quercetin-containing flavonoid extract obtained from Bulgarian Sophora japonica L. Brazilian Archives of Biology and Technology. 2013;56(3):431-438.

[29] Yang J, Guo J, Yuan J. In vitro antioxidant properties of rutin. LWT-Food Science and Technology. 2008;41(6):1060-1066.

[30] Gülçin İ. Antioxidant activity of caffeic acid (3, 4-dihydroxycinnamic acid). Toxicology. 2006;217(2-3):213220.

[31] DiNicolantonio JJ, Bhutani J, O'Keefe JH. Acarbose: safe and effective for lowering postprandial hyperglycaemia and improving cardiovascular outcomes. Open Heart. 2015;2(1):e000327.

[32] Gomis R. Inhibitors of disacaridases. Endocrinol. Nutr. 2008;55:13-16 (in Spanish).

[33] Babu PV, Liu D, Gilbert ER. Recent advances in understanding the anti-diabetic actions of dietary flavonoids. The Journal of Nutritional Biochemistry. 2013;24(11):1777-1789.

[34] Matsui T, Kobayashi M, Hayashida S, Matsumoto K. Luteolin, a flavone, does not suppress postprandial glucose absorption through an inhibition of $\alpha$-glucosidase action. Bioscience, Biotechnology, and Biochemistry. 2002;66(3):689-692.

[35] Kobori M, Masumoto S, Akimoto Y, Takahashi Y. Dietary quercetin alleviates diabetic symptoms and reduces streptozotocin-induced disturbance of hepatic gene expression in mice. Molecular Nutrition \& Food Research. 2009;53(7):859-868.

(C) 2019 by the author(s). This work is licensed under a Creative Commons Attribution 4.0 International License (http://creativecommons.org/licenses/by/4.0/). Authors retain copyright of their work, with first publication rights granted to Tech Reviews Ltd. 